\title{
Assessment of Power System Adequacy with Renewable Energy Sources and Energy Storage Systems
}

\author{
Dmitry Krupenev, ${ }^{1, *}$ \\ ${ }^{1}$ Melentiev Energy Systems Institute of Siberian Branch of the Russian Academy of Sciences, ESI SB RAS, Irkutsk, Russia
}

\begin{abstract}
The paper deals with the problem of the accounting of renewable energy sources and energy storage systems in assessment of power system adequacy. Development of renewable energy sources and energy storage systems in the present day power systems is one of the main focuses. In power systems of some countries the share of electric energy generated by renewable energy sources is above $50 \%$ in the energy balance. Therefore, the plans on development of the present day power systems must be elaborated with the proper accounting of operation of renewable energy sources and energy storage systems and the sound capacity reserves in terms of these facilities. The paper presents the algorithms for the accounting of renewable energy sources and energy storage systems. The experimental studies performed illustrate feasibility of the suggested algorithms.
\end{abstract}

\section{Introduction}

The present day power systems are characterized by the large-scale integration of renewable energy sources (RESs) and energy storage systems (ESSs). Solar and wind power plants (SPPs and WPPs, respectively) are most widely used among RESs. An extensive nomenclature of ESSs allows the use of this or that energy storage in power systems depending on the external conditions.

The key feature of RESs is their random electricity production, which depends on atmospheric and climatic conditions. Random electricity production at RESs is often weakly connected with its consumption and, therefore, has an adverse effect on electricity supply reliability. Note that sometimes electricity production at WPPs and SPPs will approach zero. As concerns ESSs, they are characterized by some specific features, which also influence electricity supply reliability within power systems.

As far as RESs and ESSs influence electricity supply reliability, they must properly be taken into account in assessment of power system reliability. This work deals with the accounting of the features of RES and ESS operation in adequacy assessment, which is a power system property to satisfy consumer requirements within the specified values and limitations on supplies of energy resources in terms of the planned and unforeseen interruptions in the work of its elements and operating constraints [1]. The accounting of RESs and ESSs in the adequacy assessment will make possible the resolution of such important, practical and critical tasks facing the electric power industry as:

- validation of RES and ESS integration into power systems;
- validation of transmission lines installation to transmit power and energy from RESs to ESSs;

- validation of generating capacity reserve levels of the power systems comprising RESs and ESSs;

- support of the required electricity supply reliability in the systems with RESs and ESSs, and other tasks.

As a rule, the power system adequacy is assessed for prospective power system schemes. This fact imposes certain limitations on the initial data on power systems, and rather, on their completeness. Really, it is not always possible to obtain accurate parameters of the commissioned equipment to be taken into account for power system adequacy assessment for a long term. The situation with the initial data on the renewable energy resource activity is the same: the models of power system adequacy assessment require special algorithms to be applied to obtain data on its activity.

\section{Power system adequacy assessment}

The current programs for power system adequacy assessment involve the estimation technique based on the Monte Carlo method [2-5]. Moreover, all active programs apply the mechanism of random events, which means independence of all generated power system states. The general scheme of the adequacy assessment technique can be presented in the following form:

1. Generation of independent calculated power system states for the considered period (as a rule, the power system adequacy is assessed for a year). A set of the calculated states is generated for each hour of the considered period with the analysis of the relative error value in the obtained result. The error value may range within $5 \%$, which is acceptable for similar calculations (some uncertainty of the initial information, discreteness

\footnotetext{
* Corresponding author: krupenev@,isem.irk.ru
} 
of the initial information, etc.). The states are generated on the basis of the Monte Carlo method. Each state contains a set of random events: failures of power system facilities, random load fluctuations, as well as scheduled repairs of facilities for the considered period. One random event $K_{i}, i=1, \ldots, n$, whose probability is equal to $P_{i}, i=1, \ldots, n$, is modeled in generation of one random number $x_{i}, i=1, \ldots, n$ from the uniformly distributed set in the interval [0,1] [6]. If $x_{i}$ is in the interval $\left[0, P_{i}\right]$, the event $K$ is considered to take place, if not, then:

$$
K_{i}=\left\{\begin{array}{l}
1, \text { если } x_{i} \in\left[0, P_{i}\right] \\
0, \text { если } x_{i} \in\left(P_{i}, 1\right]
\end{array}, i=1, \ldots, n\right.
$$

Similarly, this procedure can be extended to a greater number of incompatible events, for example, in the analysis of irregular load fluctuations, where the rule of $3 \sigma$ is used for discrete approximation of the normal distribution law of load deviations and hence, the distribution series consists of 7 steps.

2. Calculation of the conditions in the generated system states. This stage involves the calculation of the power system condition with minimum power shortage for each generated system state. To assess the power system adequacy the mathematical formulation of the problem is.

for assessment of the power shortage in the $k$-th power system state, $k=1, \ldots, N$, it is necessary to determine:

$$
\sum_{i=1}^{n}\left(\bar{y}_{i}^{k}-y_{i}\right) \rightarrow \min
$$

subject to the balance constraints

$$
\begin{gathered}
x_{i}-y_{i}+\sum_{j=1}^{n}\left(1-z_{j i} a_{j i}\right) z_{j i}-\sum_{j=1}^{n} z_{i j}=0, i=1, \ldots, n, i \neq j, \\
y_{i} \leq \bar{y}_{i}^{k}, i=1, \ldots, n, \\
x_{i} \leq \bar{x}_{i}^{k}, i=1, \ldots, n, \\
z_{i j} \leq z_{i j}^{-k}, i=1, \ldots, n, j=1, \ldots, n, i \neq j, \\
y_{i} \geq 0, x_{i} \geq 0, z_{i j} \geq 0,
\end{gathered}
$$

where: $x_{i}$ is the usable capacity at node $i, \bar{x}_{i}^{k}$ is the available generating capacity at node $i, y_{i}$ is the served load at node $i, \bar{y}_{i}^{k}$ is the load value at node $i$, $z_{i j}$ - is the power flow from node $i$ to node $j, \bar{z}_{i j}^{k}$ is the transfer capability of transmission lines between nodes $i$ and $j, a_{i j}$-are the given positive coefficients of specific power losses at its transmission from node $i$ to node $j$, $i \neq j, i=1, \ldots, n, j=1, \ldots, n, i \neq j, k=1, \ldots, N$.
3. Calculation of power system adequacy indices. After calculation of all generated states the calculated power system parameters are processed by the statistical methods, yielding a spectrum of adequacy indices. The main calculated adequacy indices are:

- the probability of failure-free operation;

- the expectation of electricity undersupply;

- the expectation of power shortage;

- the energy index of reliability;

- the probability of operating parameter deviation beyond the maximum admissible values.

\section{Modeling of RESs for power system adequacy assessment}

Wind energy is most rapidly developing among RESs to day. In 2017 the total generating capacity of WPPs in the world amounted to more than $539 \mathrm{GW}$ [7]. In many countries the wind energy share in the energy balance exceeds $20 \%$. In 2018 it is planned to put into operation above $3 \mathrm{GW}$ of wind generation in Russia by 2023 [8]. WPPs can operate both independently of the power system and in parallel with it. The central task for the latter existing and designed WPPs is their modelling for power system adequacy assessment.

WPPs are modelled using the approach described in [9]. In this approach, at the stage of forming the calculated power system states the possible failures of wind turbines were modelled at the first step and the random value of the wind speed that determines the generating capacity of wind turbines remained in operation was generated at the second step.

This study suggests a single-step procedure for determination of WPP capacity for generation of a random power system state. For this purpose prior to start the procedure of generating a random state, the distribution series of the state (operable and inoperable) of wind turbines and the wind speed are composed [2]. Then, the power generated by WPP at the specific time point is determined on the basis of the resulting series of WPP generation.

The WPP modeling algorithm for the power system adequacy assessment is as follows:

1. Generation of the series of operable and inoperable states of wind turbines at the considered WPP as a function of the emergency rate $g_{a}$ of the considered wind turbines:

$$
\left(p_{a}[X]+g_{a}[0]\right)^{o}=1,
$$

where $p_{a}$ is the probability of failure-free operation of a wind turbine; $o$ is the number of homogeneous wind turbines at the considered WPP; $X$ is the rated capacity of a turbine, $\mathrm{kW}$.

If the considered WPP has several types of wind turbines (turbines of different capacity or with different reliability and engineering characteristics), then one series is obtained by multiplication of the series of operable state of turbines. 
2. Composition of the hourly series of wind activity in the region with the installed or planned WPPs. The adequacy can be assessed by generation of the distribution series of wind speed in the considered region on the basis of the mean multi-year series, taking into account the global cyclical climate change in the considered regions, if possible.

The wind activity series for the considered region is generated by processing the hourly data on wind speeds at least for 10 previous years, yielding the distribution series of the wind speed $p_{v}[V]$ for the considered region in the form:

$$
p_{v}\left[V_{1}\right]+p_{v}\left[V_{2}\right]+\ldots+p_{v}\left[V_{10}\right]=1 \text {. }
$$

We will limit to 10 wind speed steps in the considered territory.

3. Transformation of the obtained wind activity series into the power generation series, replacing the corresponding wind speed values by generated power at this speed (dependence of the generated power on the wind speed is given in the nameplate data of the wind turbine):

$$
p_{v}\left[X_{1}\right]+p_{v}\left[X_{2}\right]+\ldots+p_{v}\left[X_{10}\right]=1 \text {. }
$$

4. Multiplication of distribution series (8) and (10).

5 . Formation of the random generating capacity state for WPP and other power system equipment by the random number generator.

The coefficient of wind speed increase depends on the wind turbine height. One more important factor to be taken into account in modeling of the hourly wind intensity is the variation of wind activity in different regions during a day, and the hourly statistics will consider these variations.

\section{Modeling of SPPs for power system adequacy assessment}

Solar energy similarly to wind energy is dynamically developing worldwide. In 2017 the installed capacity of SPPs on photovoltaic cells in the world amounted to 402 GW [6]. Another type of SPPs is the so called plants concentrating solar thermal power (CSP), whose installed capacity in 2017 made up about $5 \mathrm{GW}$ in the world [6]. In about $150 \mathrm{MW}$ to be installed before 2022 [8].

In modelling of SPPs for power system adequacy assessment it is also necessary to take into account the following two main factors: non-delivery of power by the SPPs due to technical problems caused by failures of their elements and non-delivery of power due to insufficient intensity of solar radiation.

We suggest the following algorithm for SPP modelling:

1. Determination of the distribution series of operable and inoperable states of photovoltaic and concentrated solar cells comprising a SPP:

$$
\left(p_{s}[X]+g_{s}[0]\right)^{r}=1 \text {. }
$$

where $p_{s}$ is the probability of failure-free operation of one solar cell; $g_{s}$ is the probability of failure of one solar cell; $r$ is the number of homogeneous solar cells.

If the considered SPP consists of several types of solar cells (panels) with different capacities and probabilities of failures, the common distribution series of SPP operability is obtained by multiplication of the series.

2. Determination of the hourly series of solar radiation intensity. As far as the adequacy is assessed for a longterm period and sometimes for a very long-term period (above 20 years), it is valid to apply the data on the mean multi-year values of solar radiation in the considered territory. In this case the distribution series of solar radiation for an individual hour can be of the form:

$$
p_{s}\left[R_{1}\right]+p_{s}\left[R_{2}\right]+\ldots+p_{s}\left[R_{10}\right]=1 \text {. }
$$

where $p_{s}[R]$ is the probability of solar radiation intensity.

3. Transformation of the obtained series of solar radiation intensity into the distribution series of power generation, replacing the corresponding solar radiation intensities by the power generated at this intensity:

$$
p_{s}\left[X_{1}\right]+p_{s}\left[X_{2}\right]+\ldots+p_{s}\left[X_{10}\right]=1 .
$$

In generation of series (13) account is taken of both the solar radiation intensity and the ambient temperature. Dependence of the power generated by the solar panel on the ambient temperature is presented in the nameplate data of solar panels.

3. Multiplication of the distribution series of operable and inoperable states of photovoltaic and concentrated solar panels and solar radiation intensity (11) and (13).

4. Generation of the random generating capacity state of SPP using the random number generator.

\section{Modeling of ESSs for power system adequacy assessment}

The nomenclature of ESSs integrated into the present day power systems is sufficiently extensive. Traditionally, the energy storage practice is based on the diverse methods and materials intended basically for storage of thermal and mechanical energy and subsequent conversion into electric energy. For example, the superheated steam storage tanks between the boiler and turbine are used at thermal power plants to level off the steam flow rate, when the turbine generator load is highly non-uniform over time; hot water storage tanks at cogeneration plants to provide their more uniform load during daily heat consumption fluctuations, etc.

There exist a fairly large number of diverse electricity storage units and they are steadily developing in both technology and scale.

This work deals with large power interconnections, where it is expedient to consider operation of large 
energy storage systems, participating in maintaining the energy and power balances and hence, in ensuring the required level of power system adequacy. The main characteristics of an energy storage unit from the viewpoint of its participation in these balances and the power shortage coverage are:

- the maximum capacity of an energy storage unit;

- the time of energy storage unit charge;

- the characteristic of power supply to the system by the energy storage unit depending on the residual charge;

- the energy storage unit availability to supply some part of power to the system at any time instant.

The power system adequacy is assessed in the work using the mechanism of random events that is based on the assumption of independence of all considered events. Hence, in the energy storage unit modelling to assess the power system adequacy it is necessary to take into account that:

1. In the power shortage conditions the energy storage unit must supply a maximum possible power to the power system to cover the shortage, i.e. participate as an electric energy generator;

2. In the shortage-free conditions the energy storage unit must accumulate energy, i.e. participate as an electric energy consumer;

3. Possible failures of energy storage equipment must be taken into consideration in generation of random power system states.

Thus, for power system adequacy assessment the energy storage system is specified by an additional generating unit or a group of generating units, if the energy storage system, for example, the pumped storage plant (PSP), consists of several units. It is regarded that the energy storage system involves all available resources to cover the shortage occurred in the system.

\section{Experimental studies}

The work of the suggested models is illustrated by the model of the interconnected power system (IPS) of Siberia with changed parameters, which is presented in Fig. 1. IPS of Siberia is clustered into the reliability zones in accordance with the division of the Russian Federation into its entities, except for the Bodaibo load center that is referred formally to the Irkutsk region and factually is connected with the Buryatia power system.

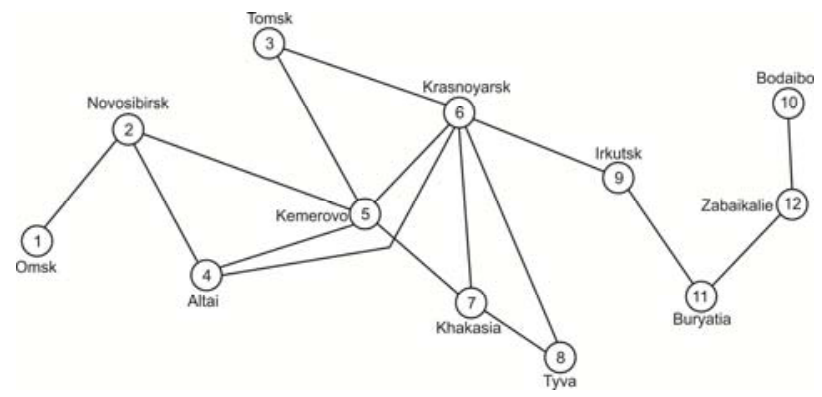

Fig. 1. Model of IPS of Siberia for adequacy assessment.

The results of operation of WPPs, SPPs and ESSs are illustrated by the characteristics of IPS of Siberia to determine the excess generating capacity, i.e. the generating capacity in the reliability zones is taken to be not real, but reduced. Table 1 presents the characteristics of the reliability zones in the calculation model of IPS of Siberia.

Table 1. Characteristics of the reliability zones of IPS of Siberia.

\begin{tabular}{|c|c|c|c|}
\hline $\begin{array}{c}\text { № } \\
\text { zone }\end{array}$ & Zone name & $\begin{array}{c}\text { Annual peak } \\
\text { load, } \\
\text { MW } \\
\end{array}$ & $\begin{array}{c}\text { Available } \\
\text { capacity, } \\
\text { MW } \\
\end{array}$ \\
\hline 1 & Omsk & 1782 & 1479 \\
\hline 2 & Novosibirsk & 2690 & 2730 \\
\hline 3 & Tomsk & 1302 & 918 \\
\hline 4 & Altai & 1884 & 1444 \\
\hline 5 & Kemerovo & 4535 & 4462 \\
\hline 6 & Krasnoyarsk & 6235 & 6848 \\
\hline 7 & Khakasia & 2155 & 5025 \\
\hline 8 & Tyva & 152 & 40 \\
\hline 9 & Irkutsk & 7570 & 9048 \\
\hline 10 & Bodaibo & 90 & 20 \\
\hline 11 & Buryatia & 945 & 898 \\
\hline 12 & Zabaikalie & 1260 & 1156 \\
\hline
\end{tabular}

Table 2 demonstrates the transfer capabilities of the interzonal tie lines in the calculation model of IPS of Siberia.

Table 2. Transfer capabilities of the interzonal tie lines of IPS of Siberia.

\begin{tabular}{|c|c|c|}
\hline $\begin{array}{c}\text { № tie } \\
\text { line }\end{array}$ & Connected zones & $\begin{array}{c}\text { Capability of } \\
\text { tie line, MW }\end{array}$ \\
\hline 1 & $\begin{array}{c}\text { 1. Omsk }-2 . \\
\text { Novosibirsk }\end{array}$ & 1305 \\
\hline 2 & $\begin{array}{c}\text { 2. Novosibirsk }-4 . \\
\text { Altai }\end{array}$ & 1440 \\
\hline 3 & $\begin{array}{c}\text { 2. Novosibirsk }-5 . \\
\text { Kemerovo }\end{array}$ & 950 \\
\hline 4 & $\begin{array}{c}3 . \text { Tomsk }-5 . \\
\text { Kemerovo }\end{array}$ & 1170 \\
\hline
\end{tabular}




\begin{tabular}{|c|c|c|}
\hline 5 & $\begin{array}{l}\text { 3. Tomsk }-6 \text {. } \\
\text { Krasnoyarsk }\end{array}$ & 780 \\
\hline 6 & $\begin{array}{l}\text { 4. Altai - } 5 . \\
\text { Kemerovo }\end{array}$ & 950 \\
\hline 7 & $\begin{array}{l}\text { 4. Altai }-6 . \\
\text { Krasnoyarsk }\end{array}$ & 850 \\
\hline 8 & $\begin{array}{l}\text { 5. Kemerovo }-6 \text {. } \\
\text { Krasnoyarsk }\end{array}$ & 1560 \\
\hline 9 & $\begin{array}{c}\text { 5. Kemerovo }-7 . \\
\text { Khakass }\end{array}$ & 1650 \\
\hline 10 & $\begin{array}{l}\text { 6. Krasnoyarsk - } \\
\text { 7. Khakass }\end{array}$ & 3400 \\
\hline 11 & $\begin{array}{c}\text { 6. Krasnoyarsk - } \\
\text { 8. Tyva }\end{array}$ & 135 \\
\hline 12 & $\begin{array}{l}\text { 6. Krasnoyarsk - } \\
\text { 9. Irkutsk }\end{array}$ & 3630 \\
\hline 13 & $\begin{array}{c}\text { 7. Khakasia }-8 . \\
\text { Tyva }\end{array}$ & 135 \\
\hline 14 & $\begin{array}{l}\text { 9. Irkutsk-11. } \\
\text { Buryatia }\end{array}$ & 885 \\
\hline 15 & $\begin{array}{c}\text { 10. } \text { Bodaibo }-11 . \\
\text { Buraytia }\end{array}$ & 66 \\
\hline 16 & $\begin{array}{l}\text { 11. Burayta }-12 . \\
\text { Zabaikalie }\end{array}$ & 410 \\
\hline
\end{tabular}

Let us locate SPPs in the Omsk power system, WPPs in the Novosibirsk power system and ESSs as PSPs in the Altai power system. The main parameters of the located objects are presented in Table 3 .

Table 3. Main parameters of WPPs, SPPs and ESs.

\begin{tabular}{|c|c|c|c|}
\hline $\begin{array}{c}\text { Reliability } \\
\text { zone }\end{array}$ & $\begin{array}{c}\text { Type of } \\
\text { located } \\
\text { object }\end{array}$ & Model x pcs.. & $\begin{array}{c}\text { Total } \\
\text { capacity, } \\
\text { MW }\end{array}$ \\
\hline Omsk & SPPs & $\begin{array}{c}\text { Eagle 72P } \\
340 \mathrm{~W} \times \\
500000\end{array}$ & 170 \\
\hline Novosibirsk & WPPs & $\begin{array}{c}\text { ENERCON E- } \\
138 \text { EP3 / 3,5 } \\
\text { MW x 50 [10] }\end{array}$ & 175 \\
\hline Altai & PSPs & POHT-115 x 2 & 230 \\
\hline
\end{tabular}

The results of a series of calculations: without commissioning of SPPs, WPPs and PSPs; with commissioning of only SPPs; with commissioning of only WPPs; with commissioning of SPPs, WPPs and PSPs are presented in Table 4.
Table 4. Calculation results.

\begin{tabular}{|c|c|c|}
\hline \multirow[b]{2}{*}{ Zone name } & \multicolumn{2}{|c|}{ Without commissioning } \\
\hline & $\begin{array}{c}\begin{array}{c}\text { Probability } \\
\text { of failure- } \\
\text { free } \\
\text { operation }\end{array} \\
\end{array}$ & $\begin{array}{c}\text { Expectation } \\
\text { of generation } \\
\text { reliability, } \\
\text { MWh }\end{array}$ \\
\hline Omsk & 0.99874 & 1826 \\
\hline Novosibirsk & 0.99994 & 64 \\
\hline Tomsk & 0.9996 & 455 \\
\hline Altai & 0.9985 & 3167 \\
\hline Kemerovo & 0.99999 & 0.0 \\
\hline Krasnoyarsk & 0.99978 & 440 \\
\hline Khakasia & 0.99999 & 0.0 \\
\hline Tyva & 0.99742 & 2075 \\
\hline Irkutsk & 0.99904 & 2321 \\
\hline Bodaibo & 0.99525 & 1050 \\
\hline Buryatia & 0.99714 & 2669 \\
\hline Zabaikalie & 0.98324 & 14994 \\
\hline System & 0,98171 & 29061 \\
\hline \multicolumn{3}{|c|}{ SPPs } \\
\hline & $\begin{array}{c}\text { Probability } \\
\text { of failure- } \\
\text { free } \\
\text { operation } \\
\end{array}$ & $\begin{array}{c}\text { Expectation } \\
\text { of electricity } \\
\text { undersupply, } \\
\text { MWh }\end{array}$ \\
\hline Omsk & 0.99946 & 550 \\
\hline Novosibirsk & 0.99993 & 60 \\
\hline Tomsk & 0.99974 & 239 \\
\hline Altai & 0.99924 & 1501 \\
\hline Kemerovo & 0.99999 & 0.0 \\
\hline Krasnoyarsk & 0.99978 & 368 \\
\hline
\end{tabular}




\begin{tabular}{|c|c|c|}
\hline Khakasia & 0.99999 & 0.0 \\
\hline Tyva & 0.99866 & 1099 \\
\hline Irkutsk & 0.99937 & 1074 \\
\hline Bodaibo & 0.99656 & 674 \\
\hline Buryatia & 0.9982 & 1712 \\
\hline Zabaikalie & 0.98521 & 12792 \\
\hline System & 0.98386 & 20069 \\
\hline \multicolumn{3}{|c|}{ WPPs } \\
\hline & $\begin{array}{c}\text { Probability } \\
\text { of failure- } \\
\text { free } \\
\text { operation } \\
\end{array}$ & $\begin{array}{c}\text { Expectation } \\
\text { of electricity } \\
\text { undersupply, } \\
\text { MWh }\end{array}$ \\
\hline Omsk & 0.99894 & 1201 \\
\hline Novosibirsk & 0.99995 & 14 \\
\hline Tomsk & 0.99956 & 726 \\
\hline Altai & 0.99861 & 2907 \\
\hline Kemerovo & 0.99999 & 0.0 \\
\hline Krasnoyarsk & 0.99962 & 697 \\
\hline Khakasia & 0.99999 & 0.0 \\
\hline Tyva & 0.99768 & 1902 \\
\hline Irkutsk & 0.99891 & 2245 \\
\hline Bodaibo & 0.99567 & 983 \\
\hline Buryatia & 0.99745 & 2403 \\
\hline Zabaikalie & 0.98286 & 14727 \\
\hline System & 0.98138 & 27805 \\
\hline
\end{tabular}

\begin{tabular}{|c|c|c|}
\hline \multicolumn{3}{|c|}{ SPPs, WPPs, PSPs } \\
\hline & $\begin{array}{c}\text { Probability } \\
\text { of failure- } \\
\text { free } \\
\text { operation } \\
\end{array}$ & $\begin{array}{c}\text { Expectation } \\
\text { of electricity } \\
\text { undersupply, } \\
\text { MWh } \\
\end{array}$ \\
\hline Omsk & 0.99974 & 227 \\
\hline Novosibirsk & 0.99996 & 10 \\
\hline Tomsk & 0.99961 & 541 \\
\hline Altai & 0.99965 & 542 \\
\hline Kemerovo & 0.99998 & 7 \\
\hline Krasnoyarsk & 0.99977 & 410 \\
\hline Khakasia & 0.99999 & 0.0 \\
\hline Tyva & 0.99913 & 732 \\
\hline Irkutsk & 0.99947 & 739 \\
\hline Bodaibo & 0.99752 & 474 \\
\hline Buryatia & 0.99897 & 924 \\
\hline Zasbaikalie & 0.98568 & 11634 \\
\hline System & 0.98449 & 16240 \\
\hline
\end{tabular}

Table 4 shows that commissioning of SPPs, WPPs, PSPs in the power systems had a positive effect on the adequacy indices.

\section{Conclusion}

The paper studies a topical problem of the modern electric power industry, namely the modelling of SPPs, WPPs and ESSs for assessment of power system adequacy. Development of modelling principles of these objects is important, since the power generation at WPPs and SPPs depends on the random character of natural phenomena, namely wind activity and solar radiation in the region. As to ESSs, the paper studies the principles of ESS accounting for adequacy assessment by the Monte Carlo method using the mechanism of random events. The testing of the suggested models and principles showed their efficiency. 


\section{References}

1. Handbook on terminology in electric power industry. (M.: Printing house "KEM", 2008) (in Russian)

2. Kovalev G.F., Lebedeva L.M. Reliability of electric power systems. (Novosibirsk: Nauka, 2015) (in Russian)

3. Chukreev Yu.Ya. Models for electric power system reliability support. (Syktyvkar, 1995) (in Russian)

4. Wenyuan Li, Probabilistic Transmission System Planning (Wiley-IEEE Press, 2011)

5. https://www.geenergyconsulting.com/practicearea/software-products/mars.

6. Krupenev D.S., Boyarkin D.A., Iakubovskii D.V. Generation of random states of electric power systems for their reliability assessment by the Monte Carlo method. Reliability and safety in energy. V.10. No. 1. (2017) (in Russian)

7. Renewables 2018 global status report (http://www.ren21.net/wpcontent/uploads/2018/06/178652_GSR2018_FullReport_web_-1.pdf)

8. List of the selected RES projects (https://www.atsenergo.ru/vie/proresults)

9. Krupenev D.S., Perzhabinsky S.M. Reliability assessment of electric power systems with wind power plants, Bulletin of the Russian Academy of Sciences. Energy. No. 2. (2017) (in Russian)

10. https://www.jinkosolar.com/index.html?lan=en

11. https://www.enercon.de/en/home/ 